\title{
原著 \\ Mutual Influences of Phonemes in Speech
}

\author{
-Electromyographic Investigation of the Orbicularis Oris Muscle-
}

\author{
Minoru Hirano and Akihiro Iwashita
}

It is presumed that in speech the articulatory movement for a certain phoneme and its acoustic pattern are influenced by the phonemes before and after it. In the present study evidence was obtained to support this presumption. When words or phrases having a labial sound in them were uttered, marked electrical activity was found in the orbicularis oris muscle not only for the labial sound but for the other sounds which would not necessarily require the contraction of this muscle. This indicates that the state of the articulatory organ for a certain phoneme is influenced by other phonemes near it.

\section{言葉の中における語音相互の影響 \\ 一口輪筋筋電図に上る研究一}

$\begin{aligned} & \text { 一口輪筋筋電図による研究一 } \\ & \text { 平 野 実* 岩下 明弘** }\end{aligned}$

緒

$\overline{\overline{\bar{D}}}$

日本語の単位は仮名一文字で表わされる 単 音 節 であ る.これは原則として 1 個の子音と 1 個の母音との結合 からなり, 前者を先行(または前置)子音, 後者を後続母 音と称する.1939年颯田 ${ }^{1)}$ は先行子音と後続母音とが相 互に影響を及ぼし合うことを音響分析学的に証明した。

これは, 同じ子音でも後続母音が異なるとその構音様式 に若干の差異があり，また同じ母音でも先行子音が異な れば，その母音が発せられる際の付属共鳴管腔の形態が 幾分異なることを示唆している.

実際に用いられる言葉は,これら単音節の連続したも のである.この場合, 同じ単音節でも前後の音節の影響 を受けてその構音様式が変化すると想像される. われわ れは口輪筋筋電図によってこの現象を立証したので報告 する.

\section{I. 研 究方 法}

研究対象は語音正常の成人男子 8 名, 女子 7 名, 計 15 名である．電極は針電極または表面電極を用い，著者の

* 久留米大学耳鼻咽喉科教室(主任：広戸幾一郎教授) **同上
1 人岩下が先に報告したのと同じ装置および方法で口輪 筋筋電図，および音声を記録し検討した（参考文献 8 参 照)，岩下が報告したごとく， 口輪筋は単音節中， 口唇 音音節 (パ行, バ行, マ行音) および母音「オ」,「ウ」 を発する時著明な筋放電を示す。その他の音節では発語 に付随して起こる口唇の運動によって弱い筋放電が認め られるが，これは必須のものではない，そこで口輪筋筋 放電の著明な音節と，しからざる音節とを種々に組み合 せた単語, あるいは句を被検者に発せしめ, その際の口 輪筋の作働状態を検討した。

\section{II. 研 究 成 績}

成績は代表的な実例について述べる.

第 1 図は同一被検者が “カッパ”および“カッター” と発音した時の口輪筋筋電図である．前者には口唇音音 節「パ」が含まれ，後者には口唇音は含まれない.“カ ッター”といった場合にはその全経過にわたって弱い放 電が認められるのみで, 個々の単音節を発する場合と同 様の放電様式である. “カッパ”という場合には「パ」 の「 $\mathrm{P}$ 」音を発するために著明な筋放電が現われるが，注 目すべきはこの放電が「力」の初まりから現われること である、すなわち, 同じ「力」という音を発する場合, 

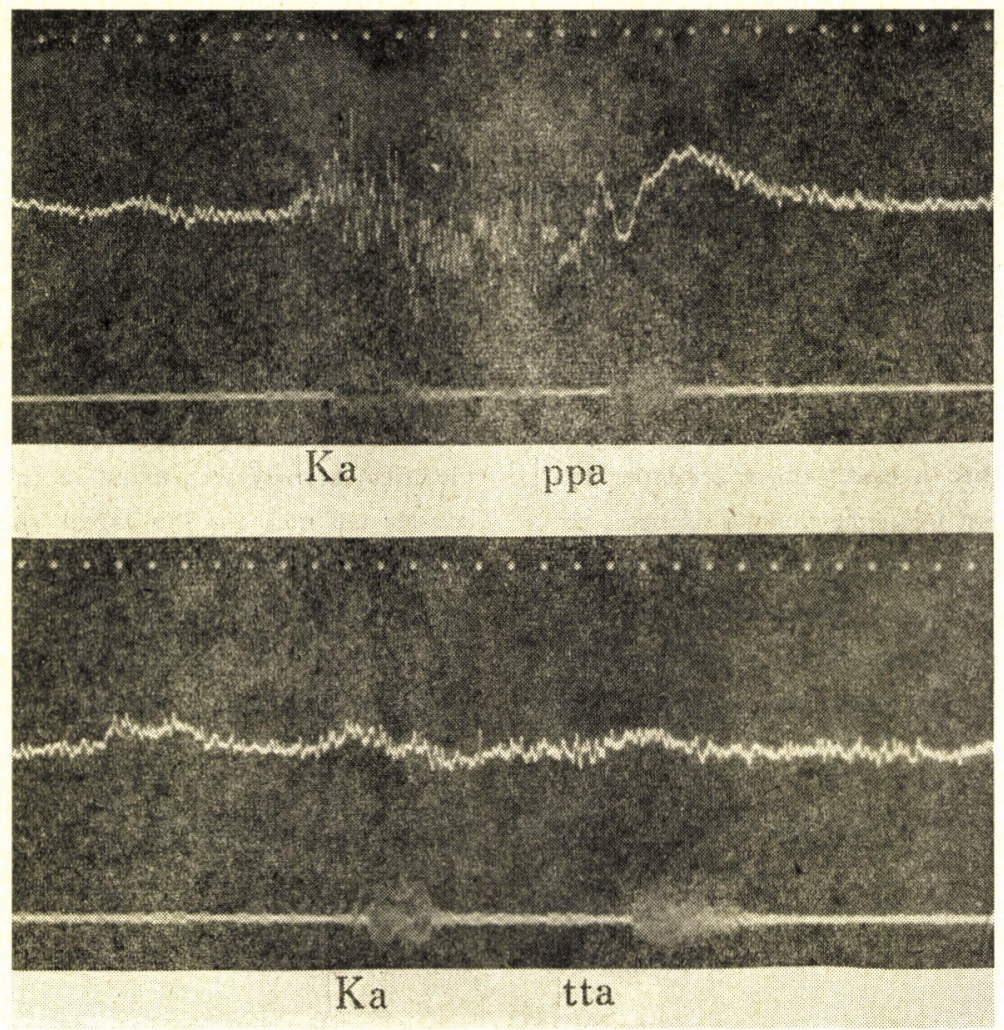

Fig. 1. Electrical activity in the orbicularis oris muscle when one subject said "kappa" and "katta". Note the pronounced electrical activity for "ka" in "kappa" as compared with for "ka" in "katta".

その後にロ唇音が続くと口輪筋に著明な緊張を伴うこと がわかる. 換言すれば “カッパ”の「カ」と“カッター”

の「カ」とでは構音器官の状態が異なるのである.

第 2 図は別の一被検者が“あかいまり”之“あかいい た”とをいった時の口輪筋筋電図である．前者には口唇 音音節「ま」が含まれ，後者には口唇音は含まれない，

“あかいはた”といった時にはその全経過にきわめて弱 い筋放電が認められるのみで, 個々の単音節を発する場 合と同様の作働状態を示す。“あかいまり”という場合 には「ま」の「m」音を発するための著明な放電が「か」 の「a」の後半部から「い」にわたって出現する.のみ ならずこの句の発せられる全経過にわたって“あかいは た”という場合に比し，強い筋放電が認められる．すな わち，口唇音を含むこの句が発せられる際には，口輪筋 に一定の緊張が保たれているのである，同じ“あかい” という単語についていえば，その後に口唇音が続く場合 としからざる場合とでは, 口輪筋の作働状態が異なる. 換言すれば構音器官の状態が異なるのである.

以上例示した現象は, 程度の差こそあれ, すべての被 検者に認められる.

\section{III. 総括ならびに考按}

日本語単音節における先行子音と後続母音との相互影

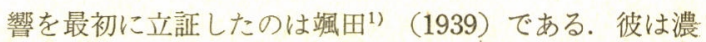
淡型トーキーフィルムの pattern および電気的周波数 分析器による音響 spectrum を検討し, 同一母音が先行 子音の種類によって顕著な変化を受けること，また同じ 子音でも後続母音によって異なる pattern を呈すること を明らかにした。これは語音の研究上きわめて重要な事 実であるが；その後この問題を特にとりあげた研究は意 外に乏しい.

近年, 梅野 ${ }^{3)}$ は高圧レ線映画により, Takahashi et al. ${ }^{4)}$ は顔面欠損患者におりる映画により鼻音音節の後 続母音では他の場合の母音と異なり, 鼻咽腔閉鎖が不完 全であることを認め, 広戸ら ${ }^{2)}$, 岩下 ${ }^{8)}$ は口蓋帆挙筋筋 電図によって同様の事実を明らかにしている.これら は, 先行子音と後続母音との相互影響という主題の下に 見出された成績ではないが, 鼻咽腔を開いて発する鼻子 音の後に続く母音が，鼻咽腔閉鎖不完全のままで発せら れているということは, 後続母音が先行子音の影響を受: 


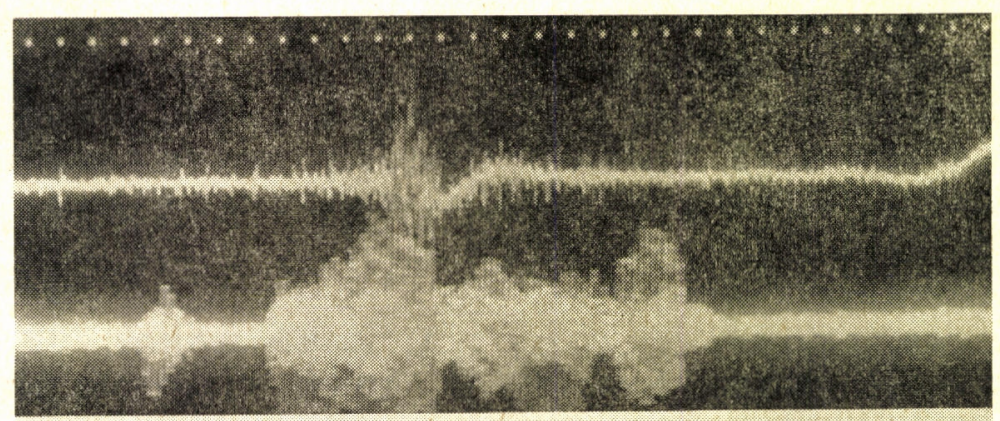

a $\quad \mathrm{ka} \quad \mathrm{i}$ m a ri

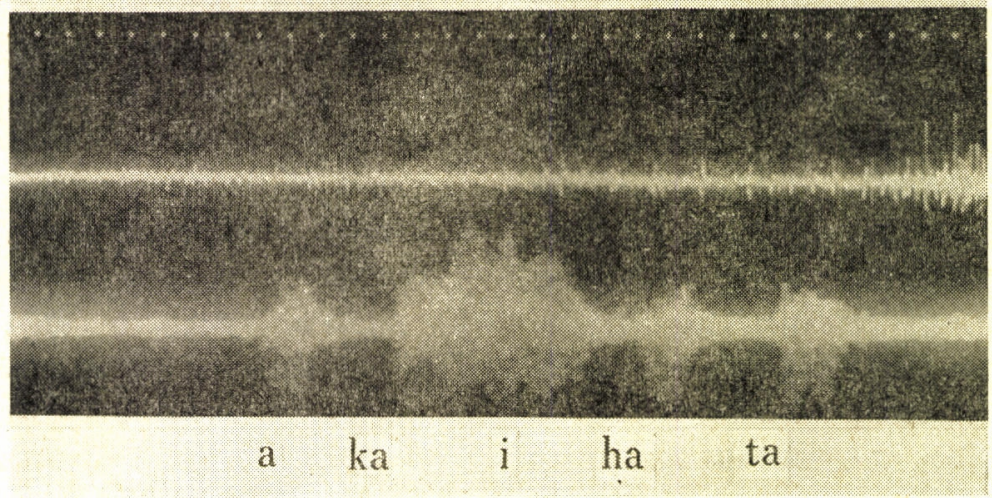

Fig. 2. Electrical activity in the orbicularis oris muscle when one subject said "akaimari" and "akaihata". Note the marked electrical activity for "akai" in "akaimari" in comparison with for "akai" in "akaihata".

けることを如実に物語っている，平野ら は単音節発語 時の鼻内音圧を測定検討した結果, 鼻音音節以外の音節 においても，後続母音を発する際の鼻咽腔閉鎖度は，先 行子音の種類によって異なると推定している.

以上はいずれも単音節についてであるが，われわれは この問題を一歩進めて, 有意多音節である単語あるいは 句について検討した， 口輪筋は舌筋，口蓋筋，咽頭収縮 筋などとともに構音器官中のきわめて重要な筋である. またこれら諸筋の中で筋電四がもっとも正確かつ容易に 誘導できる筋である，本研究に打ける示標として口輪筋 筋電図を用いたのはこの上うな理由による.

われわれの成績を要約すると, 口唇音を含む単語ある いは句（多音節語音）を発する場合には，その中の本来 口輪筋の収縮を必要としない語音が発せられる場合に も, 口輪筋の緊張を伴う、特に口展音の前の幾音節かに おいて口輪筋の収縮が著明であるということになる。こ れは多音節中の各音節が相互に影響を及ぼし合うことを

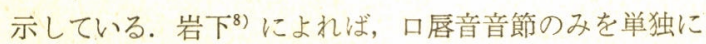
発する場合，口輪筋は音の出る約 $100 \sim 600 \mathrm{msec}$ 前から 収縮を始め，発語準備状態に入るのであるが，多音節中
ではこの発語準備状態は口唇音の幾音節か前から認めら れ，先行するそれらの音節の構音に影響を与えることは 興味深い。われわれはまだ口輪笳に関してのみしか検討 していないが，同様の現象は構音器官の他の諸筋におい ても存在すると推察される.

このような語音相互の影響には 2 つの起こり方が考え られる. 1 つは主として先行子音と後続母音との間に起 こる現象で, 子音を発する際の構音器官の形態から母音 を発する際の形態にもっとも迅速かつ円滑に移行するた めに起こるものである，例えば，鼻子音の後の母音では 鼻咽腔閉鎖が不完全なこと, 同じ「カ」行の子音「 $\mathrm{K} 」$ でも後続母音の狭窄部が前方にある「キ，ケ」では，後 続母音の狭窄部が後方にある「コ，ク」における「K」 よりも前の方で発せられることなどはこれに相当する. この上うな現象は多音節中の各音節の後続母音と, 次に 来る音節の先行子音との間にも起こり得る.こ北は発語 時の末梢構音器官に抢ける energy 消費を最小に止めよ うとする行為ともみなすことができる.

他の 1 つは本研究に示されたごとき多音節中の語音相 互の影響で,この場合にも今述べたような現象は起こり 
得るが，さらに別の mechanismを考える必要がある. 一つのまとまった多音節語音を発する場合，中枢から末 梢構音器官への命令は個々の単音節ごとに出されるので はなく, 単語, 句あるいは文章を単位として出される.

例えば“あかいまり”という場合に中枢からの命令 は，まず「あ」，次に「か」，次に「い」……いうょう に一音節づつ送られるのではなく，“あかいまり”とい う句全体を一単位として出されるのである.したがって 末梢構音器官にはこの句全体に対する発語準備状態が荷 せられ，その状態の下で各音節が順次発せられるのであ る.そこで個々の音節もしくは子音，母音が直接相互に 影響し合うというよりは, 各音節もしくは子音, 母音は それらの組み合せによってできた句全体を通して，他の 語音の影響を受けていると考えられる.

同じ子音，母音あるいは音節でも，その前後の語音の 影響を受けて，その構音様式もしくは音響学的性格が種 々に変化修飾されるという事実は, 語音の研究に際して 常に念頭におくべき重要なことである．語音の研究に当 っては, 対象とした語音が言葉の中のいかなる場におい て発せられたかを仔細に検討せねばならない，ある語音 について得られた研究成績がいかなる言葉の場において も認められるものなのか, ある特殊の場においてのみ認 められるものなのかを明確にしておかないと, 結論を誤 る恐れがあるからである.

$$
\text { 結語 }
$$

単語, 句など多音節語音を発する場合に, これを構成
する各語音は互いに影響を及ぼし合うことを口輪筋筋電 図によって明らかにした。

終りに臨み恩師広戸幾一郎教授のご指導ご校閲に深謝 いたします。本論文の要旨は第 298 回日耳鼻九州地方 会, 第 8 回日本音声言語医学会において講演した。

\section{文献}

1）端田琴次：発声機構および語音調節について。 日 耳鼻会報. $45: 1590-1688 ， 1939$.

2）広戸幾一郎・他：語音発声時における構音運動の 筋電図学的研究. 音声言語医学. $3: 14,1962$.

3）梅野正義：高压レ線映画による語音発声時の軟口 蓋並びに舌根部運動に関する研究.耳鼻臨床. 55 ： 305-340, 1962.

4) Takahashi, H. et al.: Studies on the movement of the nasopharyngeal wall related to speech. Studia phonologica. II : 47-60, 1962.

5）平野 実・他：語音発声時の畜内音圧に関する実 験的研究. 耳鼻臨床. $56: 87-102,1963$.

6) 広戸幾一郎 - 他: 電気的構音器官模型. 医用電子 と生体工学. 2:205-216, 1964.

7) 広戸幾一郎 - 他 : 電気的構音器官模型 electrical vocal tract analog について. 耳鼻臨床. $57: 395$ $-403,1964$.

8）岩下明弘：語音発声機構に関する筋電困学的研 究. 耳鼻臨床. $58: 712-734,1965$. 